\title{
Circulating Insulin-Like Growth Factor I is Involved in the Effect of High Fat Diet on Peripheral Amyloid $\beta$ Clearance
}

\author{
Raquel Herrero-Labrador ${ }^{1,2}$, Angel Trueba-Saiz ${ }^{1,2}$, Laura Martinez-Rachadell ${ }^{1,2}$, \\ $M^{a}$ Estrella Fernandez de Sevilla ${ }^{1,2} \mathbb{D}^{-}$, Jonathan A. Zegarra-Valdivia ${ }^{1,2,3} \mathbb{C}$, Jaime Pignatelli ${ }^{1,2}$, \\ Sonia Diaz-Pacheco ${ }^{1}$, Ana M. Fernandez ${ }^{1,2}$ and Ignacio Torres Aleman 1,2,*(D) \\ 1 Cajal Institute, CSIC, 28002 Madrid, Spain; rhlabrador@cajal.csic.es (R.H.-L.); angelts86@gmail.com (A.T.-S.); \\ rachadell@cajal.csic.es (L.M.-R.); mefernandezdesevilla@cajal.csic.es (M.E.F.d.S.); \\ zegarra@cajal.csic.es (J.A.Z.-V.); pigna@cajal.csic.es (J.P.); soniadiaz@cajal.csic.es (S.D.-P.); \\ anaf@cajal.csic.es (A.M.F.) \\ 2 Ciberned, 28029 Madrid, Spain \\ 3 Universidad Nacional de San Agustín de Arequipa, 04001 Arequipa, Peru \\ * Correspondence: ignacio.torres@achucarro.org
}

Received: 22 October 2020; Accepted: 16 December 2020; Published: 18 December 2020

\begin{abstract}
Obesity is a risk factor for Alzheimer's disease (AD), but underlying mechanisms are not clear. We analyzed peripheral clearance of amyloid $\beta(A \beta)$ in overweight mice because its systemic elimination may impact brain A $\beta$ load, a major landmark of AD pathology. We also analyzed whether circulating insulin-like growth factor I (IGF-I) intervenes in the effects of overweight as this growth factor modulates brain $A \beta$ clearance and is increased in the serum of overweight mice. Overweight mice showed increased $A \beta$ accumulation by the liver, the major site of elimination of systemic $A \beta$, but unaltered brain $A \beta$ levels. We also found that $A \beta$ accumulation by hepatocytes is stimulated by IGF-I, and that mice with low serum IGF-I levels show reduced liver A $\beta$ accumulation-ameliorated by IGF-I administration, and unchanged brain A $\beta$ levels. In the brain, IGF-I favored the association of its receptor (IGF-IR) with the $A \beta$ precursor protein (APP), and at the same time, stimulated non-amyloidogenic processing of APP in astrocytes, as indicated by an increased sAPP $\alpha / \mathrm{sAPP} \beta$ ratio after IGF-I treatment. Since serum IGF-I enters into the brain in an activity-dependent manner, we analyzed in overweight mice the effect of brain activation by environmental enrichment (EE) on brain IGF-IR phosphorylation and its association to APP, as a readout of IGF-I activity. After EE, significantly reduced brain IGF-IR phosphorylation and APP/IGF-IR association were found in overweight mice as compared to lean controls. Collectively, these results indicate that a high-fat diet influences peripheral clearance of $A \beta$ without affecting brain $A \beta$ load. Increased serum IGF-I likely contributes to enhanced peripheral $A \beta$ clearance in overweight mice, without affecting brain $A \beta$ load probably because its brain entrance is reduced.
\end{abstract}

Keywords: diet; A $\beta$ clearance; IGF-I; Alzheimer disease

\section{Introduction}

Obesity is considered a risk factor for AD [1-3]. However, the relationship between body weight and dementia appears complex [4-6], and recent observations even pose a protective role of late-life excess weight in AD [7]. Taking into account the worrying worldwide prevalence of obesity and dementia [8,9], greater knowledge of possible links between the two conditions is imperative. Amyloid $\beta(A \beta)$ handling may be one such link, as this peptide is considered a major pathogenic factor in AD and obesity-associated inflammation [10] may interfere with its elimination from the brain. 
In turn, we recently proposed that insulin peptides such as insulin and insulin-like growth factor I (IGF-I), may be involved in the connection between lifestyle and AD risk [11], although apparently, contradictory evidence links IGF-I with AD. Thus, circulating IGF-I has been reported to favor brain $\mathrm{A} \beta$ clearance [12], while IGF-IR seems to interfere with proteostasis, favoring brain accumulation of $A \beta$ [13]. Of note, hepatocytes, the main source of circulating IGF-I [14], are the major disposal system for circulating $A \beta$ in mice [15], and previous evidence has shown that insulin, a hormone closely related to IGF-I, favors $A \beta$ uptake by hepatocytes [16].

IGF-I may not only be involved in brain A $\beta$ clearance but also in its production. Accordingly, an effect of IGF-I was observed on APP processing towards the non-amyloidogenic pathway, reducing in this way its production [17-19]. However, IGF-I has also been shown to stimulate the amyloidogenic pathway $[20,21]$. Thus, the actions of IGF-I on $A \beta$ production are not yet clear either.

Significantly, the actions of circulating IGF-I in the brain are modulated by diet [22]. Brain IGF-I is in part locally synthesized [23], and in part derived from uptake from the circulation [24]. The entrance of circulating IGF-I into the brain is activity-dependent and tightly regulated [25], probably because it participates in many essential brain functions [26]. Furthermore, the entrance of serum IGF-I into the brain may be altered in pathological conditions, as seen by us in stressed animals [11].

In the present work, we investigated the regulation of peripheral $A \beta$ clearance in overweight mice and the possible role of circulating IGF-I.

\section{Results}

\subsection{High Fat Diet Influences Peripheral A $\beta$ Disposal and Serum IGF-I Levels}

We examined plasma $A \beta$ clearance through liver uptake using fluorescent $A \beta_{1-40}$ [27]. While $A \beta_{1-42}$ is an important component of brain $A \beta$ plaques, $A \beta_{1-40}$ is the major form of soluble, circulating $A \beta$. The liver is the major systemic disposal route of $A \beta[15]$, and peripheral $A \beta$ disposal is a proposed mechanism for central $A \beta$ clearance [28]. We injected fluorescently tagged $A \beta_{1-40}$ through the tail vein of overweight mice under high-fat diet (HFD) and their lean controls receiving a standard diet. Ninety minutes later, animals were culled, and fluorescence levels were examined in the liver and plasma. Compared to controls, overweight mice showed significantly increased fluorescence accumulation in the liver and decreased in serum, suggesting increased uptake of fluorescent $A \beta_{1-40}$ by hepatocytes, leading to its increased clearance in serum (Figure 1A). Since circulating IGF-I may affect $A \beta$ clearance [12], we examined serum IGF-I levels in overweight mice and found them increased (Figure 1B). However, when we measured endogenous soluble brain $A \beta_{1-40}$ levels with a sensitive mouse-specific ELISA that detects its monomeric forms, similar $A \beta_{1-40}$ levels were found in intact overweight mice, as compared to control lean mice (Figure 1C). Since serum IGF-I levels are increased in overweight mice (Figure 1B), we determined whether brain IGF-I is correspondingly higher, as serum IGF-I crosses the BBB [24]. However, overweight mice showed normal brain IGF-I levels (Figure 1D).

\subsection{IGF-I Promotes A $\beta$ Uptake by Hepatocytes}

To try to clarify the discrepancy between increased peripheral disposal of $A \beta$ and normal brain load, we analyzed a possible role of IGF-I in peripheral A $\beta$ clearance, which predominantly takes place in the liver [14]. As brain cells take up A $\beta$ to clear it [29], we determined whether IGF-I modulates in vitro uptake by hepatocytes of fluorescently labeled $A \beta$, as an indirect measure of its potential effects on $A \beta$ disposal by the liver. In the presence of IGF-I $(10 \mathrm{nM})$, hepatocytes accumulated significantly more fluorescence, suggesting a stimulatory action of IGF-I on A $\beta$ uptake by these cells (Figure 2A). Moreover, liver IGF-I deficient (LID) mice with a 70\% reduction in circulating IGF-I [30] showed reduced liver accumulation of tagged $A \beta$ after intravenous injection, while blood levels were increased, as compared to controls, indicating reduced liver clearance (Figure 2B). Of note, IGF-I treatment of LID mice ameliorated these deficits (Figure 2B). However, as in overweight mice, LID mice did not show changes in brain $A \beta_{1-40}$ levels (Figure $2 \mathrm{C}$ ). 
A

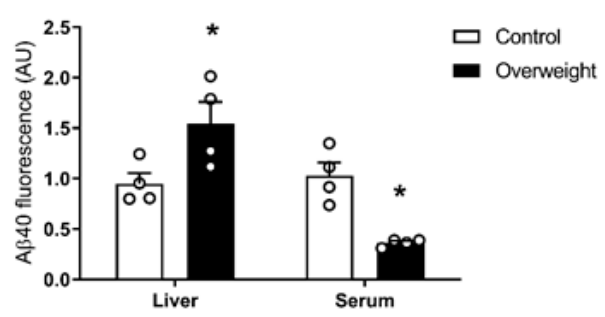

C

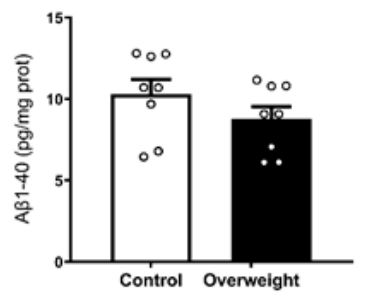

B

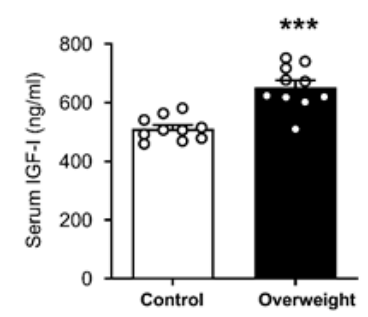

D

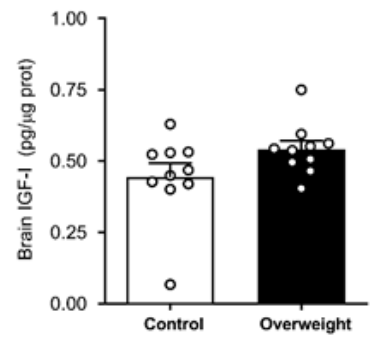

Figure 1. Influence of high fat diet on $A \beta$ and IGF-I levels. (A) Overweight mice show significantly increased fluorescence in the liver and reduced in serum, suggesting increased uptake of fluorescently labeled $\mathrm{A} \beta_{1-40}$ by the liver and increased clearance from serum ( $n=4$ per group). (B) Serum levels of IGF-I are increased after 10 weeks of a high-fat diet ( $n=10$ per group). (C) Brain $\mathrm{A} \beta_{1-40}$ levels remain unaltered in overweight mice as compared to lean controls $(n=6-8) .{ }^{*} p<0.05$ and ${ }^{* * *} p<0.001$. (D) Brain levels of IGF-I were normal in high fat diet (HFD)-fed overweight mice ( $n=10$ per group).

A
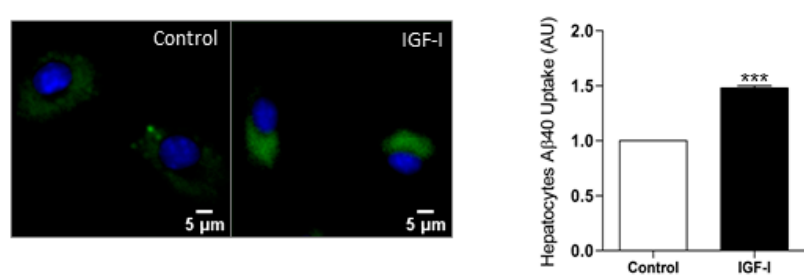

B

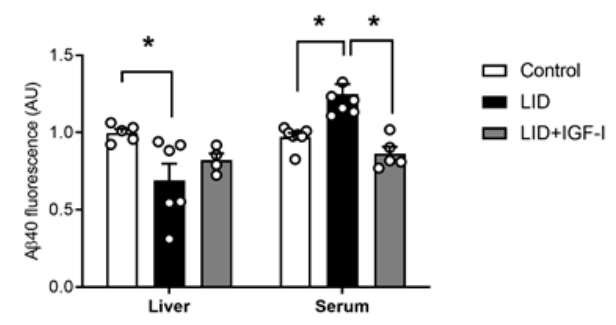

C

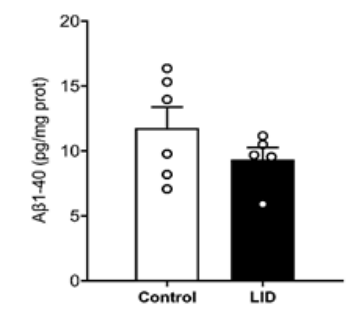

Figure 2. Modulation by IGF-I of $A \beta$ uptake by hepatocytes. (A) IGF-I induces uptake of $A \beta$ by hepatocytes $(n=6)$. Representative micrograph of cultured hepatocytes with internalized fluorescent $\mathrm{A} \beta$ (green). Cell nuclei stained with Hoescht. Lower histograms: Quantification of intracellular fluorescent $A \beta$ after IGF-I treatment. (B) Serum IGF-I deficient mice (liver IGF-I deficient (LID) mice) show reduced $\mathrm{A} \beta$ uptake by the liver, which was ameliorated by systemic IGF-I treatment $(n=5$ control/6 LID/5 LID + IGF-I). (C) Brain A $\beta$ levels did not change in LID mice $(n=8) .{ }^{*} p<0.05$ and ${ }^{* * *} p<0.001$. 


\subsection{Cell-Specific Actions of IGF-I in APP Metabolism by Brain Cells}

IGF-I has been reported to promote either amyloidogenic [20], or non-amyloidogenic [18] APP processing pathways in neuronal cell lines. To clarify its role in primary cells, we analyzed the actions of IGF-I on amyloidogenic and non-amyloidogenic APP processing by astrocytes and neurons, the primary sources of A $\beta$ in the brain [31,32]. Using the soluble APP metabolites sAPP $\beta$ and sAPP $\alpha$ as markers of the amyloidogenic and the non-amyloidogenic pathway, respectively, we found that IGF-I modulates their production in a cell-specific fashion. In astrocytes, secretion of both soluble forms of APP was stimulated by IGF-I, whereas in neurons, IGF-I inhibited their secretion (Figure 3A). However, the APP $\alpha / \mathrm{sAPP} \beta$ ratio was increased in both cell types, indicating that the net action of IGF-I is to promote the non-amyloidogenic processing of APP (Figure 3B).

A
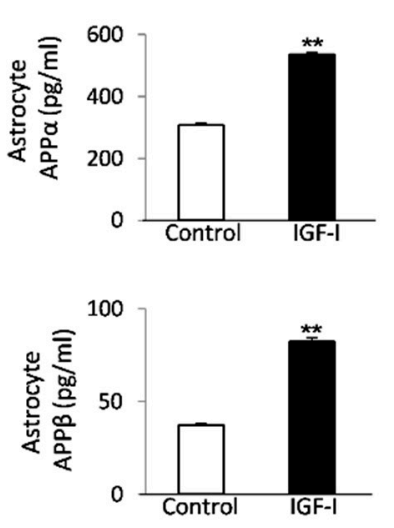

C

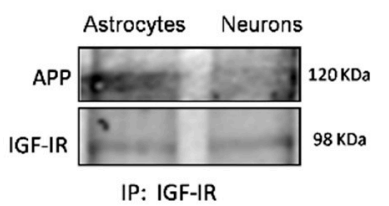

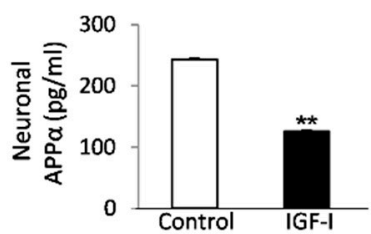

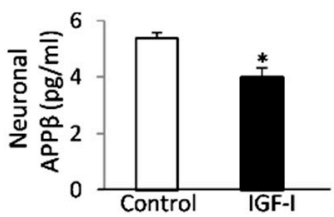

B
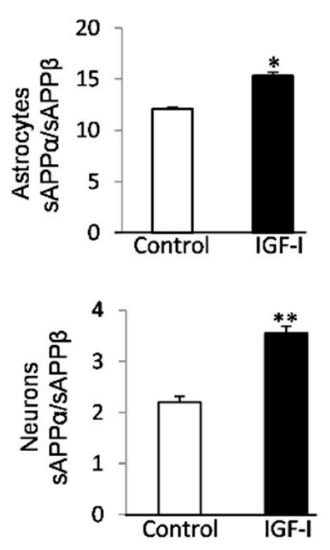

D
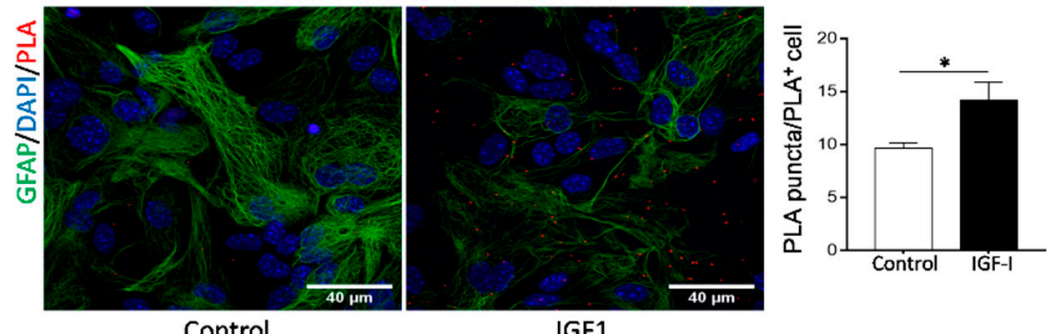

IGF1

Figure 3. $A \beta$ precursor protein (APP) processing in astrocytes is modulated by IGF-I. (A) IGF-I stimulated the secretion of both SAPP $\alpha$ and SAPP $\beta$ in cultured astrocytes (left histograms) while inhibited it in neurons (right histograms, $n=4$ ). (B) However, IGF-I increased the $\operatorname{sAPP} \alpha / \mathrm{sAPP} \beta$ ratio in both cell types, indicating a net non-amyloidogenic action of IGF-I in these cells. (C) IGF-IR and APP co-immunoprecipitate in cultured astrocytes, while in neurons, the interaction is negligible. (D) Proximity ligation assays (PLA) of APP and IGF-IR in cultured astrocytes confirm the interaction of both proteins that are upregulated by IGF-I $(n=3)$. Cell nuclei stained with Hoescht. ${ }^{*} p<0.05$ and ** $p<0.01$.

Since both IGF-IR and APP associate to LRP1 and APP processing depends on its subcellular localization [33], we assessed whether IGF-IR and APP interact with each other. Indeed, IGF-IR and APP co-immunoprecipitated in astrocytes, whereas in neurons, the interaction was negligible (Figure 3C). Proximity ligation assays (PLA) confirmed a robust interaction of APP with IGF-IR in astrocytes (Figure 3D), while in neurons, the interaction was negligible (not shown). Treatment of astrocytes with IGF-I resulted in a significantly increased interaction between both proteins, as determined by a stronger PLA signal (Figure 3D). 
Since IGF-I promotes A $\beta$ uptake by hepatocytes [34], we examined whether it exerts similar action in brain cells. In this organ, the main cell types involved in $A \beta$ clearance are microglia and astrocytes through its uptake and degradation $[35,36]$ and endothelial cells at the blood-brain-barrier (BBB) through efflux of brain A $\beta$ into the circulation [37]. We found that IGF-I promoted A $\beta$ uptake by astrocytes (Figure 4A) while it decreased it in microglia (Figure 4B). In brain endothelial cell cultures mimicking the BBB architecture [25], IGF-I did not significantly affect A $\beta$ efflux from the "brain" side to the "blood" side of the double chamber, although it was slightly reduced (Figure 4C).

A
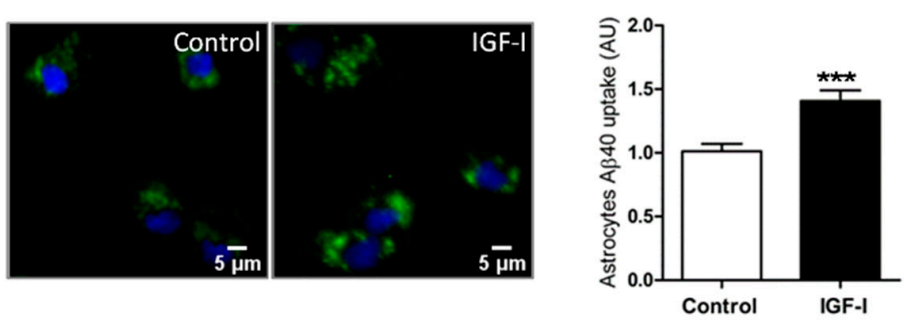

B

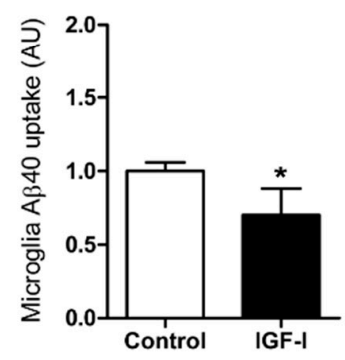

C

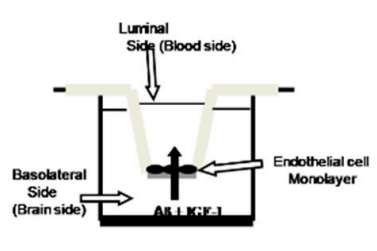

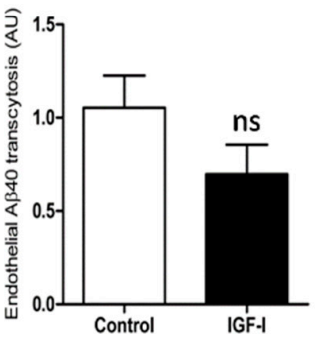

Figure 4. IGF-I modulates brain $\mathrm{A} \beta$ uptake in a cell-specific manner. (A) $\mathrm{A} \beta$ uptake by astrocytes is significantly increased by IGF-I $(n=8)$. Representative photomicrograph showing uptake by cultured astrocytes of fluorescently labeled $A \beta$ (green). Cell nuclei stained with Hoescht. (B) $A \beta$ uptake by microglia is significantly reduced by IGF-I $(n=7)$. (C) IGF-I did not significantly affect brain-to-blood efflux in an in vitro system mimicking the blood-brain-barrier (cartoon in the left). The amount of $\mathrm{A} \beta$ in the upper chamber was quantified $15 \mathrm{~h}$ after adding it to the lower chamber in the presence or absence of IGF-I $(n=6) .{ }^{*} p<0.05,{ }^{* * *} p<0.001$ and not-significant (ns).

\subsection{Reduced Brain IGF-I Activity in Overweight Mice}

To tried to explain the discrepancy between peripheral and central IGF-I levels in overweight mice, we determined whether the passage of serum IGF-I into the brain is reduced in them. To this end, we took advantage that exposure to environmental enrichment (EE) stimulates the passage of serum IGF-I into the brain in normal mice [25]. We tested whether overweight mice would show an altered passage of IGF-I after EE by measuring Tyr-phosphorylation of brain IGF-I receptors as a proxy of their activity. While basal levels of brain Tyr phosphorylation of IGF-IR were similar in control and overweight mice, after EE, the latter showed reduced IGF-IR phosphorylation (Figure 5A), pointing to the impaired entrance of circulating IGF-I. In addition, we used the interaction of IGF-IR with APP seen in vitro as an additional indicator of the entrance of IGF-I into the brain of EE-stimulated overweight mice. Significantly, whereas in lean mice, EE produced enhanced brain APP/IGF-IR interactions, 
in overweight mice, this interaction was significantly smaller (Figure 5B), pointing to the reduced entrance of IGF-I.

A
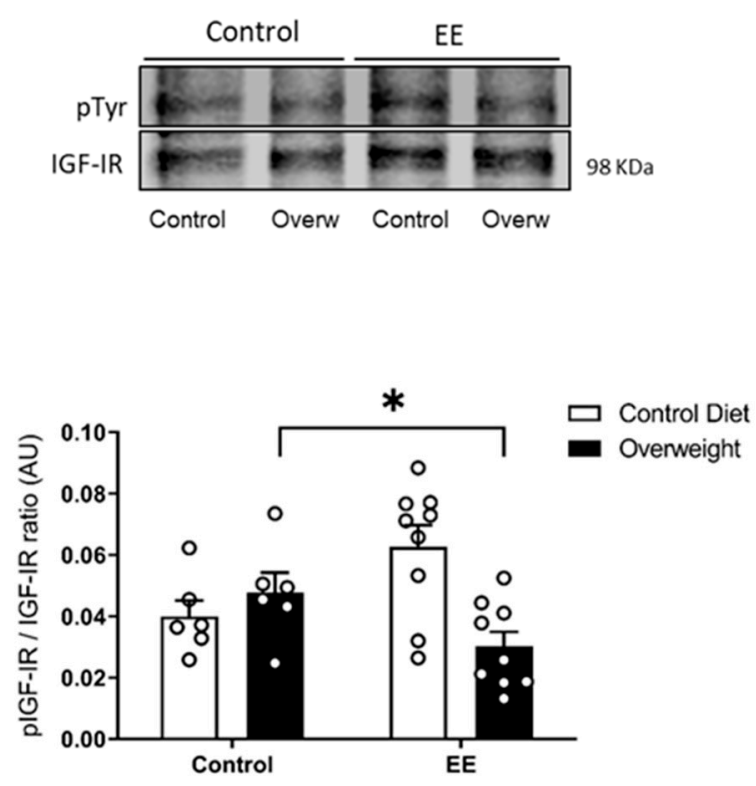

B
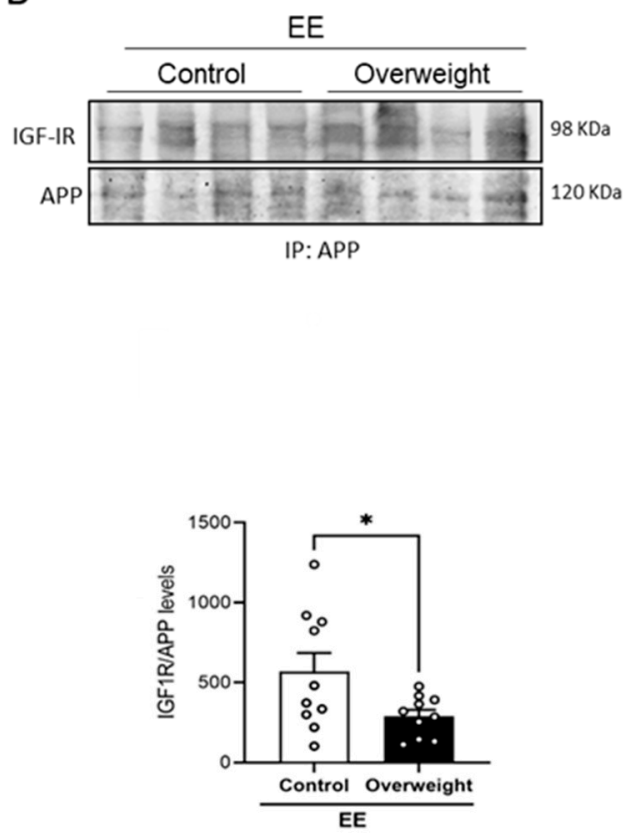

Figure 5. Reduced entrance of serum IGF-I in overweight mice. (A) In response to environmental enrichment (EE), overweight mice show lower brain IGF-IR phosphorylation than lean mice receiving a standard diet ( $n=10 \mathrm{EE} / 6$ Control, for each diet). (B) Interaction of APP with IGF-IR in the brain of mice submitted to EE stimulation was significantly decreased in overweight mice ( $n=10$ per group). Representative blots are shown, together with quantification histograms. ${ }^{*} p<0.05$.

\section{Discussion}

These results suggest that in adult normal mice, a high fat diet influences plasma $\mathrm{A} \beta$ clearance through the liver, and that circulating IGF-I may play a role in this effect. Of note, no correlation was found between increases or decreases in peripheral $A \beta$ clearance and brain $A \beta$ levels. These observations agree with previous ones showing that reducing peripheral $A \beta$ does not affect brain $A \beta$ levels or that there is no correlation between central and peripheral A $\beta$ levels in AD patients [38-41]. Compartmentalization of $A \beta$ clearance may be reflecting multiple sources of this circulating peptide, as under normal physiological circumstances, $A \beta$ is produced not only in the brain but throughout the body.

However, other observations do not support the compartmentalization of $A \beta$ clearance. Thus, increased peripheral $A \beta$ levels after anti-A $\beta$ treatment were reported to parallel a decrease of brain $A \beta$; reducing peripheral $A \beta$ was sufficient to reduced brain $A \beta$, and recent studies favor a diagnostic utility of the relationship between plasma and CSF $A \beta_{1-42}[28,42,43]$. Thus, the relationship between peripheral and central $A \beta$ is still under debate [44]; indeed, a substantial part of brain $A \beta$ clearance in humans takes place in the periphery [45], and reduction of peripheral $A \beta$ reduces its content in the CSF [46].

In turn, normal brain levels of $A \beta$ in overweight mice agree with previous observations [47], although increased brain $A \beta$ load in overweight mice was found by others $[48,49]$. Conversely, enhanced elimination of circulating $A \beta$ in overweight mice favors the notion that a higher body mass index may be protective rather than detrimental for AD risk [4]. Although counter-intuitive, the normal brain $A \beta$ load seen by us in overweight mice may fit with this notion, as a HFD may produce higher brain $A \beta$ levels that could be cleared faster and, therefore, no changes would be 
detected. In addition, other still undefined systemic changes may contribute to brain $A \beta$ load in $A D$, as recently postulated [50].

Among the latter, we considered circulating IGF-I as a probable systemic factor influencing AD. Indeed, there are many reports indicating a relationship of circulating IGF-I with the disease, although no consensus has been reached on whether it exerts a beneficial or detrimental action [51], or could serve as a biomarker of the evolution of AD $[52,53]$. The initial observation that IGF-I is involved in brain $A \beta$ clearance [12]—although this has been questioned [54], supported these studies. In relation to the present findings, IGF-I is known to show diet-sensitive actions in the brain [22]. Further, previous studies using the APP/PS1 mouse model of AD had shown that HFD interferes with central and peripheral insulin signaling [55], which is largely shared by IGF-I. These authors also found impaired insulin signaling in wild-type mice submitted to HFD, which agrees with our present findings. Hence, several observations favor involvement of impaired activity of circulating IGF-I in the actions of a high-fat diet on peripheral A $\beta$ clearance. (1) IGF-I levels are increased in overweight mice, (2) IGF-I, as previously seen with insulin [16], stimulates the uptake of A $\beta$ by hepatocytes, and (3) LID mice with low serum IGF-I show reduced peripheral $\mathrm{A} \beta$ clearance that was ameliorated by treatment with systemic IGF-I. Thus, higher serum IGF-I levels in overweight mice may contribute to enhance plasma $A \beta$ clearance without affecting brain $A \beta$ load. The latter disagrees with our previous observation of increased brain $A \beta$ levels in LID mice [12]. The use of an in-house ELISA and formic acid extraction of total brain $\mathrm{A} \beta$ (prior results) vs. a commercial ELISA with guanidinium $\mathrm{HCl}$ extraction of brain $\mathrm{A} \beta$ (current results), and/or changing housing conditions of LID mice over time in our animal facility (i.e., sterile food pellets) affecting their microbiome [56], that shows strong interactions with IGF-I function [57], may explain this discrepancy. However, we do not have a straightforward explanation of this important difference with our previous results.

As indicated by an increased sAPP $\alpha / \mathrm{SAPP} \beta$ ratio in IGF-I-treated neurons and astrocytes, the net action of IGF-I on the main cell types producing $A \beta$ in the brain is to increase non-amyloidogenic processing of APP, contributing in this way to lower its brain levels and enhance neuroprotection, as SAPP $\alpha$ is neuroprotective acting in part through IGF-IR [58]. Thus, the overall action of IGF-I in the brain may be anti-amyloidogenic. Further studies using the SAPP $\alpha / \mathrm{sAPP} \beta$ ratio in brain samples will help confirm this observation. Intriguingly, insulin favors $A \beta$ secretion in neurons [59], suggesting a complex interplay of these hormones in regulating brain $\mathrm{A} \beta$ levels. At the same time, reduced IGF-I entrance in the brain of overweight mice may hamper its anti-amyloidogenic actions. Indeed, overweight mice showed not only reduced entrance of serum IGF-I in response to EE stimulation, as determined by reduced brain IGF-IR phosphorylation but also reduced APP/IGF-IR interaction. In previous work, we documented an inhibitory effect of triglycerides (TGLs) in BBB entrance of IGF-I across the choroid plexus [22]. It is possible that high serum TGLs as a result of the high-fat diet also interferes with the BBB entrance of IGF-I across brain endothelial cells in overweight mice, as previously seen for other circulating hormones such as insulin [60] or leptin [61].

Reduced IGF-I entrance would affect its pro-clearance actions on brain A $\beta[12,62]$. In addition, we cannot discard that the inhibitory actions of IGF-I on A $\beta$ uptake by microglia may also counteract its actions on astrocytes (but see below). Alternatively, brain $A \beta$ levels may not be affected by peripheral $A \beta$ clearance, or other factors may also contribute to it, such as the recently postulated vascular drainage $[63,64]$. Interestingly, insulin also enhances the degradation of $A \beta$ and its clearance in astrocytes [65] and hepatocytes [16], respectively. Thus, these two closely related hormones may modulate $\mathrm{A} \beta$ disposal in a concerted manner, as previously reported for glucose handling [66].

IGF-I stimulates $A \beta$ uptake by astrocytes, while inhibits it in microglia. Whereas, astrocytes appear critical to determine $A \beta$ load [67], and increased clearance of $A \beta$ by astrocytes may result in reduced $A \beta$ plaques [36], inhibition of $A \beta$ uptake by microglia may also reduce plaques [68], as the role of microglial uptake of $A \beta$ in plaque formation may be detrimental $[69,70]$. In accordance with a stimulatory effect of IGF-I on astrocytes, previous observations suggested that astrocyte-derived IGF-I protects neurons against $\mathrm{A} \beta$ toxicity through a mechanism involving its uptake [71]. 
The observed astrocyte-specific interaction of APP with IGF-IR and on SAPP $\alpha$ and sAPP $\beta$ levels may be related to a differential processing of APP by IGF-I in these cells since its processing depends on its intracellular localization [33]. Of the different isoforms of APP, the major one expressed in neurons is $\mathrm{APP}_{695}$, which lacks the extracellular Kunitz protease inhibitor (KPI) protein-protein interaction domain KPI. This domain is present in the longer isoforms, $\mathrm{APP}_{751}$ and $\mathrm{APP}_{770}$, which are the most abundant types in glial cells [72]. It is possible that KPI is involved in the observed interactions with IGF-IR in astrocytes, but this requires further analysis. In turn, a trend of IGF-I to inhibit brain efflux of $A \beta$ through BBB endothelial cells would favor its accumulation in the brain parenchyma [73]. We previously reported that IGF-I stimulates $A \beta$ efflux through the choroid plexus BBB [12], an observation supported by the reducing effects of in vivo IGF-I administration on brain A $\beta$ levels $[12,62]$. Thus, IGF-I may show site-specific effects on A $\beta$ efflux through BBB cells.

Several limitations of this study need to be pointed out. We determined plasma $A \beta$ clearance using exogenously added tagged $A \beta$. Measuring dynamic changes in circulating levels of endogenous $A \beta$ in overweight mice would be necessary to firmly establish that peripheral $A \beta$ clearance is enhanced. However, available methods of quantification of serum $A \beta$ are not sensitive enough to reliably detect decreases in non-transgenic mice. Further, since other organs also accumulate and degrade circulating $A \beta$, they may also contribute to diet influence on plasma $A \beta$ clearance. In addition, whether diet influences clearance of other circulating peptides needs to be clarified. Finally, mice with low serum IGF-I (LID mice) present insulin resistance [74], which may affect the ability of hepatocytes to take up and degrade $A \beta$.

\section{Materials and Methods}

\subsection{Materials}

Human IGF-I was purchased from PeProTec (London, UK). Primary antibodies were monoclonal anti-IGF-I receptor (1:1000; Santa Cruz Biotechnology, Dallas, TX, USA), monoclonal anti-APP (Nt 22C11; Millipore; 1:200), for PLA studies, polyclonal anti-APP (1:200; Sigma, Madrid, Spain), for immunoprecipitation, and monoclonal anti-pTyr (1:1000, Transduction Labs, BD BioSciences, San Jose, CA, USA). Secondary antibodies were goat anti-rabbit $(1: 20,000)$ or mouse IRDye-coupled (1:20,000), both from LI-COR (Lincoln, NE, USA).

\subsection{Animals}

New-born wild type (WT) C57BL6/J mice were used for cell cultures, and WT and liver IGF-I deficient (LID mice; bred in-house, congenic with C57/BL6/J) male adult mice (3-5 months old) were used for the rest of the experiments. LID mice presented low levels of serum IGF-I due to the disruption of the liver IGF-I gene with the albumin-Cre/Lox system [14]. Serum IGF-I deficient mice have normal body and brain weights, and they do not show any major developmental defects [14,75]. In rescuing experiments, LID mice were treated with subcutaneous hIGF-I ( $5 \mu \mathrm{g} / \mathrm{kg} /$ day) for 30 days, using osmotic pumps (1004 Alzet, Durect Corp, Cupertino, CA, USA) following the manufacturer's instructions. Animal procedures followed the European (86/609/EEC and 2003/65/EC, European Council Directives) and approval of the local Bioethics Committee.

\subsection{High Fat Diet}

Wild type C57BL6/J mice were fed for 10 weeks with either a control diet (ref E15000-04), or a high-fat $\operatorname{diet}(\mathrm{HFD}$ ) with $45 \% \mathrm{KJ}$ fat $+1.25 \%$ cholesterol (ref E15744-34), both purchased from ssniff Spezialdiäten $\mathrm{GmbH}$ (Soest, Germany). After 10 weeks, animals were overweight (Supplementary Figure S1A), developed glucose intolerance (Supplementary Figure S1B), together with hyperinsulinemia and insulin resistance (not shown). 


\subsection{Cell Cultures}

Astroglial cultures with $>95 \%$ GFAP-positive cells were prepared as described [76]. Postnatal (day 1-2) brains were dissected, the forebrain removed, and mechanically dissociated. The resulting mixed cell suspension was centrifuged and plated in DMEM/F-12 (Life Technologies, Carlsbad, CA, USA) with $10 \%$ fetal bovine serum (Life Technologies) and $100 \mathrm{mg} / \mathrm{mL}$ of antibiotic-antimycotic solution (Sigma-Aldrich, Madrid, Spain). When confluent, cells were shaken $\left(210 \mathrm{rpm} / 37^{\circ} \mathrm{C} / 3 \mathrm{~h}\right.$ ) to detach microglial cells. For microglial cultures, supernatants were centrifuged (1000 rpm/5 min), re-suspended in DMEM/F12 (Life Technologies) + FBS (Gibco, Gaithersburg, MD, USA), HS, and penicillin/streptomycin solution. Cells were seeded at $12.5 \times 10^{4} \mathrm{cells} / \mathrm{cm}^{2}$ in a multi-well coated with poly-L-lysine [77] and cultured for 2 days. Cells were then changed to DMEM/F12 for $3 \mathrm{~h}$ until A $\beta$ uptake was carried out (see below). Astrocytes were then collected from the same flasks that microglia was obtained, as follows. After removing the microglia-containing supernatant, the medium was replaced, and flasks were shaken for $15 \mathrm{~h} / 280 \mathrm{rpm}$. Cells were then trypsinized and seeded at $3.75 \times$ $10^{4}$ cells $/ \mathrm{cm}^{2}$ in the same culture medium, replaced every 4 days. When $80 \%$ confluency was reached, astrocytes were cultured for $3 \mathrm{~h}$ with DMEM/F12 before the different assays were initiated (see below). Endothelial cell cultures were performed as described [77]. Briefly, dissection was performed on ice, and cortices were cut into small pieces $\left(1 \mathrm{~mm}^{3}\right)$, digested in a mixture of collagenase/dispase (270 U collagenase $/ \mathrm{mL}, 10 \%$ dispase) and DNAse $(10 \mathrm{U} / \mathrm{mL})$ in DMEM for $1.5 \mathrm{~h}$ at $37^{\circ} \mathrm{C}$. The cell pellet was separated by centrifugation in $20 \%$ bovine serum albumin/DMEM $(1000 \times g, 5 \mathrm{~min})$. Capillary fragments were retained on a $10 \mu \mathrm{m}$ nylon filter, removed from the filter with endothelial cell basal medium (Life Technologies, Waltham, MA, USA), supplemented with $20 \%$ bovine plasma-derived serum and antibiotics (penicillin, $100 \mathrm{U} / \mathrm{mL}$; streptomycin, $100 \mu \mathrm{g} / \mathrm{mL}$ ), and seeded on $60 \mathrm{~mm}$ Petri dishes multi-well plate coated with collagen type IV $\left(5 \mu \mathrm{g} / \mathrm{cm}^{2}\right)$ and fibronectin $\left(1 \mu \mathrm{g} / \mathrm{cm}^{2}\right) .3 \mu \mathrm{g} / \mathrm{mL}$ puromycin was added for 3 days, removed from the culture medium, and replaced by fibroblast growth factor $(2 \mathrm{ng} / \mathrm{mL})$ and hydrocortisone $(1 \mu \mathrm{g} / \mathrm{mL})$. For hepatocytes cultures, adult ( 2 months old) control animals were anesthesized (pentobarbital $50 \mathrm{mg} / \mathrm{kg}$ ), and the hepatic portal vein exposed to inject a solution containing $\mathrm{NaCl}(118 \mathrm{Mm}), \mathrm{KCl}(4.7 \mathrm{Mm}), \mathrm{KH}_{2} \mathrm{PO}_{4}(1.2 \mathrm{Mm}), \mathrm{NaHCO}_{3}(25 \mathrm{Mm})$, glucose $(5.5 \mathrm{Mm})$, and EGTA $(0.5 \mathrm{Mm})$ at $37 \mathrm{C}$. The inferior cava vein was cut to open the circuit. Thereafter the same solution without EGTA and containing $\mathrm{CaCl}_{2}(2 \mathrm{Mm}), \mathrm{MgSO}_{4}(1.2 \mathrm{Mm})$, and collagenase $(90 \mathrm{U} / \mathrm{mL})$ were perfused. The liver was dissected and placed in DMEM/F12-10\% FBS with penicillin/streptomycin, filtered in a 70 um Nylon mesh, centrifuged ( $60 \times g, 5 \mathrm{~min})$, and re-suspended in DMEM/F12-10\% FBS with $45 \%$ Percoll ${ }^{\circledR}$ (Sigma Aldrich). Cells were then re-suspended and washed 3X in DMEM/F12-10\% FBS using $200 \times g, 10$ min spins, before plating them at $8.25 \times 10^{4}$ cells/collagen-coated multi-well. Cultures were kept 2 days before use.

\subsection{Glucose Tolerance Test (GTT)}

Mice were fasted for $6 \mathrm{~h}$ and left isolated in individual cages (with water but no food access) for at least $30 \mathrm{~min}$ before starting the test to avoid any stress-related effect on glycemia [78]. For the glucose tolerance test (GTT), an overload of glucose $(2 \mathrm{~g} / \mathrm{kg})$ was injected intraperitoneally. The aqueous solution was left overnight at room temperature, thus the $\beta$-form of glucose was enriched. Blood samples were extracted from the tip of the tail at times $0,15,30,60$, and 90 to measure glucose levels with a glucometer (Menarini Diagnosis, Florence, Italy).

\subsection{Environmental Enrichment}

Mice were submitted to environmental enrichment, as explained in detail elsewhere [79]. Briefly, animals were placed for $2 \mathrm{~h}$ in a large cage, 10 animals/cage, and with different objects (cardboard tunnels, shelters of different materials, a plastic net, toys, chewable, and nesting material). Thereafter, they were sacrificed, and their brain collected for immunoprecipitation and western blot analysis. 


\subsection{A U Utake}

$\mathrm{A} \beta$ uptake was used as a proxy of its clearance as cells take it up to subsequently degrade it.

In vitro: Cells were treated during $15 \mathrm{~h}$ with $500 \mathrm{nM}$ soluble A $\beta 40$-HiLyte Fluor ${ }^{\mathrm{TM}} 488$ (AnaSpec, San Jose, CA, USA) [80], and IGF-I (1 $\mathrm{nM}$ in glial cultures, $10 \mathrm{nM}$ in hepatocytes). Thereafter, cultures were washed with PBS pH 6.0 to eliminate membrane-bound A $\beta$ followed by PBS pH 7.4. Cell nuclei were stained with Hoechst 33,342 (Thermo Fisher Scientific, Waltham, MA, USA; 1:500) in PBS pH 7.4/5 min, fluorescent images were taken in a DMI 6000 (Leica) microscope using Exc: $350 \mathrm{~nm} / \mathrm{Em}$ : $461 \mathrm{~nm}$ for Hoeschst dye and Exc: $503 \mathrm{~nm} / \mathrm{Em}$ : $528 \mathrm{~nm}$ for fluorescently labeled A $\beta$. Thereafter, cells were lysed in Tris- $\mathrm{HCl}(10 \mathrm{mM}) \mathrm{pH} 8.0$, guanidine $(50 \mathrm{mM})$, and spun at $14.000 \mathrm{rpm}$ for $10 \mathrm{~min}$ at $4{ }^{\circ} \mathrm{C}$. Fluorescence was quantified in a FLUOStar OPTIMA (BMG Labtech, Thermo Fisher) at Exc: 485 nm/Em: $520 \mathrm{~nm}$. In transcytosis assays using brain endothelial cells, A $\beta 40-$ HiLyte Fluor $^{\mathrm{TM}} 488$ soluble $(500 \mathrm{nM})$ was added in the bottom compartment (Figure 4C) with or without $1 \mathrm{nM}$ IGF-I, and after $15 \mathrm{~h}$ the culture medium from the upper chamber was collected and fluorescence measured in the fluorimeter, as above.

In vivo: A $\beta 40-H i L y t e$ Fluor ${ }^{\mathrm{TM}} 488(400 \mu \mathrm{g} / \mathrm{kg})$ was injected into the tail vein using a $0.38 \mathrm{~mm}$ cannula (Intramedic, Madrid, Spain), and after 90 min mice were sacrificed, blood taken from the heart and liver dissected. This timing was chosen based on previous observations of peak plasma $\mathrm{A} \beta$ clearance [27]. Liver tissue was homogenized in Tris- $\mathrm{HCl}(10 \mathrm{mM}) \mathrm{pH} 8.0$-guanidine $(50 \mathrm{mM})$. Fluorescence in serum and liver extracts was quantified by fluorimetry, as above. Values were normalized per $\mathrm{ml}$ of serum or $\mathrm{mg}$ of protein. The latter was measured in liver samples using the BCA system (Sigma).

\subsection{Immunoassays}

Immunoprecipitation (IP) was performed as described before [81]. In brief, cultured cells or brain tissue were homogenized in ice-cold buffer with $10 \mathrm{mM}$ Tris $\mathrm{HCl}$ pH 7.5, $150 \mathrm{mM} \mathrm{NaCl}, 1 \mathrm{mM}$ EDTA, $1 \mathrm{mM}$ EGTA, $1 \%$ Triton X-100, 0.5\% NP40, 1 mM sodium orthovanadate, and a protease inhibitor cocktail (Sigma) plus $2 \mathrm{mM}$ PMSF, using $1 \mathrm{~mL}$ of buffer per $\mathrm{mg}$ of tissue. Insoluble material was removed by centrifugation, and supernatants were incubated overnight at $4{ }^{\circ} \mathrm{C}$ with the antibodies: Monoclonal anti-APP (22C11, Millipore, Watford, UK), monoclonal anti-pTyr (PY20, BD Transduction Labs), or polyclonal anti-IGF-IR (D23H3, Cell Signalling, Danvers, MA, USA). Immunocomplexes were collected with Protein A/G agarose (Santa Cruz Biotechnology, Sta Cruz, CA, USA) for $1 \mathrm{~h}$ at $4{ }^{\circ} \mathrm{C}$ and washed $3 \mathrm{X}$ in homogenization buffer before separation by SDS-polyacrylamide gel electrophoresis and transferred to nitrocellulose membranes. After blocking for $1 \mathrm{~h}$ with 5\% BSA in TTBS $(20 \mathrm{mM}$ Tris-HCl, pH 7.4, 150 $\mathrm{M} \mathrm{NaCl}, 0.1 \%$ Tween 20), membranes were incubated overnight at $4{ }^{\circ} \mathrm{C}$ with the different antibodies in TTBS, washed, incubated with secondary antibodies and develop using the Odissey procedure (Lycor Biosciences, Lincoln, USA). Immunoprecipitates with non-immune IgG and total lysates (input) were blotted with anti-IGFIR as controls (see Supplementary Figure S1C). A representative IP blot is shown from a total of at least 3 independent experiments. GFAP immunocytochemistry in cultured cells followed previously published procedures [81]. In brief, cultured cells were incubated to block non-specific antibody binding, followed by incubation overnight at $4{ }^{\circ} \mathrm{C}$ with anti-GFAP in phosphate buffer (PB)-1\% bovine albumin-1\% Triton X-100 (PBT). After several washes in PB, sections were incubated with an Alexa-coupled secondary antibody (1:1000, Molecular Probes, Eugene, USA) diluted in PBT. Finally, a 1:500 dilution (in PBS) of DAPI (Hoechst 33342) was added for $3 \mathrm{~min}$. Wells were rinsed several times in PB $0.1 \mathrm{~N}$, mounted with $15 \mu \mathrm{L}$ of gerbatol mounting medium, and allowed to dry. The omission of the primary antibody was used as a control. Microphotographs were taken in a Leica (Wetzlar, Germany) microscope.

IGF-I in serum and brain was determined using a species-specific ELISA (R\&D Systems, Minneapolis, USA), as described in detail elsewhere [26]. Murine A $\beta$ (Thermo Fisher Scientific) was determined by ELISA in brain lysates, following the manufacturer's instructions. This commercial system rules out background signal due to non-APP proteins, as indicated elsewhere using brain lysates from APP knock out mice [82]. Brain A $\beta$ was extracted by tissue homogenization in $200 \mathrm{mM}$ 
guanidine- $\mathrm{HCl}, 20 \mathrm{mM}$ Tris- $\mathrm{HCl}, \mathrm{pH} 8.0$ with protease inhibitors. Then, the homogenate was mixed for $3 \mathrm{~h}$, centrifuged at $15,000 \times \mathrm{g}$ for $20 \mathrm{~min}$ at $4{ }^{\circ} \mathrm{C}$, and the supernatant diluted two-fold with Standard diluent buffer included in the kit. The ELISA procedure was carried out following the manufacturer's instructions. Murine sAPP $\alpha$ and SAPP $\beta$ were determined by ELISA in culture supernatants. Brain samples were normalized with total protein determined by BCA method (Sigma-Aldrich). Blood was collected from the heart after pentobarbital anesthesia and thereafter brains were dissected and frozen at $-80{ }^{\circ} \mathrm{C}$ until used.

\subsection{Proximity Ligation Assays (PLA)}

Assays were performed as described [83]. Amyloid precursor protein (APP)—IGF-IR interactions were detected in astrocytes and neurons grown on glass coverslips using the Duolink II in situ PLA detection Kit (OLink; Bioscience, Sweden). Cultured cells were fixed in 4\% paraformaldehyde $/ 10 \mathrm{~min}$, washed with PBS containing $20 \mathrm{mM}$ glycine to quench the aldehyde groups, permeabilized with the same buffer containing $0.05 \%$ Triton X-100 for $5 \mathrm{~min}$, and washed with PBS. After $1 \mathrm{~h} / 37^{\circ} \mathrm{C}$ with the blocking solution in a pre-heated humidity chamber, cells were incubated overnight in antibody diluent medium with primary antibodies: Mouse monoclonal anti-APP and rabbit polyclonal anti-IGF-I receptor, and processed following the instructions of the supplier using the PLA probes detecting rabbit or mouse antibodies (Duolink II PLA probe anti-Rabbit plus, and Duolink II PLA probe anti-Mouse minus, diluted 1:5 in antibody diluent), and a DAPI-containing mounting medium.

\subsection{Statistical Analysis}

Data were analyzed with GraphPad Prism 6.0 software. A normal distribution Kolmogorov-Smirnov test was carried out in all experiments and a non-parametric Wilcoxon test was applied accordingly. For samples with normal distribution, parametric tests include one or two-way ANOVA followed by a Bonferroni or $t$-test. A $p<0.05$ was considered significant.

\section{Conclusions}

In summary, a high fat diet influences peripheral $A \beta$ clearance. A lack of correlation between peripheral clearance and central $A \beta$ load further supports a non-linear relationship between both compartments. Actions of IGF-I on A $\beta$ handling may be related to diet influences on AD pathology; therefore, cellular sites of IGF-I interaction may constitute new druggable targets, through, for example, potentiating the passage of circulating IGF-I into the brain across the BBB. However, caution is needed as previous attempts to exploit IGF-I as a therapeutic effector in AD have been unfruitful [84].

Supplementary Materials: Supplementary Materials are available online at http://www.mdpi.com/1422-0067/21/ 24/9675/s1.

Author Contributions: R.H.-L. performed experiments, analyzed results, and wrote part of the manuscript. A.T.-S. performed experiments and analyzed results. L.M.-R. performed experiments and analyzed results. M.E.F.d.S. performed experiments and analyzed results. J.P. performed experiments and analyzed results. J.A.Z.-V. and S.D.-P. helped with experiments. A.M.F. performed experiments and analyzed results. I.T.A. designed the study, analyzed results, and wrote the manuscript. All authors have read and agreed to the published version of the manuscript.

Funding: This work was funded by a grant from Ciberned, by an Inter-CIBER project (PIE14/00061), and from SAF2013-40710-R (AEI/FEDER, UE). J.A.Z.-V. acknowledges the financial support of the National Council of Science, Technology and Technological Innovation (CONCYTEC, Perú) through the National Fund for Scientific and Technological Development (FONDECYT, Perú).

Acknowledgments: We are thankful to M. Garcia and R. Cañadas for technical support.

Conflicts of Interest: The authors declare no conflict of interest. 


\section{Abbreviations}

$\begin{array}{ll}\text { A } \beta & \text { amyloid } \beta \\ \text { AD } & \text { Alzheimer disease } \\ \text { APP } & \text { amyloid precursor protein } \\ \text { BBB } & \text { blood-brain-barrier } \\ \text { EE } & \text { environmental enrichment } \\ \text { FBS } & \text { fetal bovine serum } \\ \text { GTT } & \text { glucose tolerance test } \\ \text { HFD } & \text { high fat diet } \\ \text { IGF-I } & \text { insulin-like growth factor I } \\ \text { IGF-IR } & \text { IGF-I receptor } \\ \text { KPI } & \text { Kunitz protease inhibitor } \\ \text { LID } & \text { liver IGF-I deficient } \\ \text { LRP1 } & \text { lipoprotein receptor related protein 1 } \\ \text { NHS } & \text { normal horse serum } \\ \text { PB } & \text { phosphate buffer } \\ \text { PBS } & \text { phosphate buffer saline } \\ \text { PLA } & \text { proximity ligation assay }\end{array}$

\section{References}

1. Kivimaki, M.; Luukkonen, R.; Batty, G.D.; Ferrie, J.E.; Pentti, J.; Nyberg, S.T.; Shipley, M.J.; Alfredsson, L.; Eleonor, I.F.; Goldberg, M.; et al. Body mass index and risk of dementia: Analysis of individual-level data from 1.3 million individuals. Alzheimers Dement 2018, 14, 601-609. [CrossRef] [PubMed]

2. Profenno, L.A.; Porsteinsson, A.P.; Faraone, S.V. Meta-analysis of Alzheimer's disease risk with obesity, diabetes, and related disorders. Biol. Psychiatry 2010, 67, 505-512. [CrossRef] [PubMed]

3. Singh-Manoux, A.; Dugravot, A.; Shipley, M.; Brunner, E.J.; Elbaz, A.; Sabia, S.; Kivimaki, M. Obesity trajectories and risk of dementia: 28 years of follow-up in the Whitehall II Study. Alzheimers Dement 2018, 14, 178-186. [CrossRef] [PubMed]

4. Lee, C.M.; Woodward, M.; Batty, G.D.; Beiser, A.S.; Bell, S.; Berr, C.; Bjertness, E.; Chalmers, J.; Clarke, R.; Dartigues, J.-F.; et al. Association of anthropometry and weight change with risk of dementia and its major subtypes: A meta-analysis consisting 2.8 million adults with 57294 cases of dementia. Obes. Rev. 2020, 21, e12989. [CrossRef] [PubMed]

5. Dye, L.; Boyle, N.B.; Champ, C.; Lawton, C. The relationship between obesity and cognitive health and decline. Proc. Nutr. Soc. 2017, 76, 443-454. [CrossRef] [PubMed]

6. Jimenez, A.; Pegueroles, J.; Carmona-Iragui, M.; Vilaplana, E.; Montal, V.; Alcolea, D.; Videla, L.; Illan-Gala, I.; Pane, A.; Casajoana, A.; et al. Weight loss in the healthy elderly might be a non-cognitive sign of preclinical Alzheimer's disease. Oncotarget 2017, 8, 104706-104716. [CrossRef]

7. Sun, Z.; Wang, Z.-T.; Sun, F.-R.; Shen, X.-N.; Xu, W.; Ma, Y.-H.; Dong, Q.; Tan, L.; Yu, J.-T. Alzheimer's Disease Neuroimaging, I. Late-life obesity is a protective factor for prodromal Alzheimer's disease: A longitudinal study. Aging (Albany NY) 2020, 12, 2005-2017. [CrossRef]

8. Scheltens, P.; Blennow, K.; Breteler, M.M.; de Strooper, B.; Frisoni, G.B.; Salloway, S.; Van der Flier, W.M. Alzheimer's disease. Lancet 2016, 388, 505-517. [CrossRef]

9. Engin, A. The Definition and Prevalence of Obesity and Metabolic Syndrome. Adv. Exp. Med. Biol. 2017, 960, $1-17$.

10. Cox, A.J.; West, N.P.; Cripps, A.W. Obesity, inflammation, and the gut microbiota. Lancet Diabetes Endocrinol. 2015, 3, 207-215. [CrossRef]

11. Fernandez, A.M.; Santi, A.; Torres Aleman, I. Insulin Peptides as Mediators of the Impact of Life Style in Alzheimer's disease. Brain Plast. (Amst. Neth.) 2018, 4, 3-15. [CrossRef]

12. Carro, E.; Trejo, J.L.; Gomez-Isla, T.; LeRoith, D.; Torres-Aleman, I. Serum insulin-like growth factor I regulates brain amyloid-beta levels. Nat. Med. 2002, 8, 1390-1397. [CrossRef] [PubMed] 
13. Cohen, E.; Paulsson, J.F.; Blinder, P.; Burstyn-Cohen, T.; Du, D.; Estepa, G.; Adame, A.; Pham, H.M.; Holzenberger, M.; Kelly, J.W.; et al. Reduced IGF-1 signaling delays age-associated proteotoxicity in mice. Cell 2009, 139, 1157-1169. [CrossRef] [PubMed]

14. Yakar, S.; Liu, J.L.; Stannard, B.; Butler, A.; Accili, D.; Sauer, B.; LeRoith, D. Normal growth and development in the absence of hepatic insulin-like growth factor I. Proc. Natl. Acad. Sci. USA 1999, 96, 7324-7329. [CrossRef] [PubMed]

15. Ghiso, J.; Shayo, M.; Calero, M.; Ng, D.; Tomidokoro, Y.; Gandy, S.; Rostagno, A.; Frangione, B. Systemic Catabolism of Alzheimer's A $\beta 40$ and A $\beta 42$. J. Biol. Chem. 2004, 279, 45897-45908. [CrossRef] [PubMed]

16. Tamaki, C.; Ohtsuki, S.; Terasaki, T. Insulin facilitates the hepatic clearance of plasma amyloid beta-peptide (1 40) by intracellular translocation of low-density lipoprotein receptor-related protein 1 (LRP-1) to the plasma membrane in hepatocytes. Mol. Pharmacol. 2007, 72, 850-855. [CrossRef] [PubMed]

17. Jacobsen, K.T.; Adlerz, L.; Multhaup, G.; Iverfeldt, K. Insulin-like growth factor-1 (IGF-1)-induced processing of amyloid- $\beta$ precursor protein (APP) and APP-like protein 2 is mediated by different metalloproteinases. J. Biol. Chem. 2010, 285, 10223-10231. [CrossRef]

18. Adlerz, L.; Holback, S.; Multhaup, G.; Iverfeldt, K. IGF-1-induced processing of the amyloid precursor protein family is mediated by different signaling pathways. J. Biol. Chem. 2007, 282, 10203-10209. [CrossRef]

19. Zhang, H.; Gao, Y.; Dai, Z.; Meng, T.; Tu, S.; Yan, Y. IGF-1 reduces BACE-1 expression in PC12 cells via activation of PI3-K/Akt and MAPK/ERK1/2 signaling pathways. Neurochem. Res. 2011, 36, 49-57. [CrossRef]

20. Araki, W.; Kume, H.; Oda, A.; Tamaoka, A.; Kametani, F. IGF-1 promotes beta-amyloid production by a secretase-independent mechanism. Biochem. Biophys. Res. Commun. 2009, 380, 111-114. [CrossRef]

21. Costantini, C.; Scrable, H.; Puglielli, L. An aging pathway controls the TrkA to p75NTR receptor switch and amyloid beta-peptide generation. EMBO J. 2006, 25, 1997-2006. [CrossRef] [PubMed]

22. Dietrich, M.O.; Muller, A.; Bolos, M.; Carro, E.; Perry, M.L.; Portela, L.V.; Souza, D.O.; Torres-Aleman, I. Western Style Diet Impairs Entrance of Blood-Borne Insulin-like Growth Factor-1 into the Brain. Neuromolecular. Med. 2007, 9, 324-330. [CrossRef] [PubMed]

23. Bach, M.A.; Shen-Orr, Z.; Lowe, W.L., Jr.; Roberts, C.T., Jr.; LeRoith, D. Insulin-like growth factor I mRNA levels are developmentally regulated in specific regions of the rat brain. Brain Res. Mol. Brain Res. 1991, 10, 43-48. [CrossRef]

24. Carro, E.; Nunez, A.; Busiguina, S.; Torres-Aleman, I. Circulating insulin-like growth factor I mediates effects of exercise on the brain. J. Neurosci. 2000, 20, 2926-2933. [CrossRef]

25. Nishijima, T.; Piriz, J.; Duflot, S.; Fernandez, A.M.; Gaitan, G.; Gomez-Pinedo, U.; Verdugo, J.M.; Leroy, F.; Soya, H.; Nunez, A.; et al. Neuronal activity drives localized blood-brain-barrier transport of serum insulin-like growth factor-I into the CNS. Neuron 2010, 67, 834-846. [CrossRef] [PubMed]

26. Trejo, J.L.; Piriz, J.; Llorens-Martin, M.V.; Fernandez, A.M.; Bolos, M.; LeRoith, D.; Nunez, A.; Torres-Aleman, I. Central actions of liver-derived insulin-like growth factor I underlying its pro-cognitive effects. Mol. Psychiatry 2007, 12, 1118-1128. [CrossRef]

27. Hone, E.; Martins, I.J.; Fonte, J.; Martins, R.N. Apolipoprotein E influences amyloid-beta clearance from the murine periphery. J. Alzheimers Dis. 2003, 5, 1-8. [CrossRef]

28. DeMattos, R.B.; Bales, K.R.; Cummins, D.J.; Dodart, J.C.; Paul, S.M.; Holtzman, D.M. Peripheral anti-A beta antibody alters CNS and plasma A beta clearance and decreases brain A beta burden in a mouse model of Alzheimer's disease. Proc. Natl. Acad. Sci. USA 2001, 98, 8850-8855. [CrossRef]

29. Mandrekar, S.; Jiang, Q.; Lee, C.Y.D.; Koenigsknecht-Talboo, J.; Holtzman, D.M.; Landreth, G.E. Microglia mediate the clearance of soluble Abeta through fluid phase macropinocytosis. J. Neurosci. Off. J. Soc. Neurosci. 2009, 29, 4252-4262. [CrossRef]

30. Zegarra-Valdivia, J.A.; Santi, A.; Fernandez de Sevilla, M.E.; Nunez, A.; Torres Aleman, I. Serum Insulin-Like Growth Factor I Deficiency Associates to Alzheimer's Disease Co-Morbidities. J. Alzheimers Dis. 2019, 69, 979-987. [CrossRef]

31. Kamenetz, F.; Tomita, T.; Hsieh, H.; Seabrook, G.; Borchelt, D.; Iwatsubo, T.; Sisodia, S.; Malinow, R. APP processing and synaptic function. Neuron 2003, 37, 925-937. [CrossRef] 
32. Zhao, J.; O'Connor, T.; Vassar, R. The contribution of activated astrocytes to Abeta production: Implications for Alzheimer's disease pathogenesis. J. Neuroinflamm. 2011, 8, 150. [CrossRef] [PubMed]

33. Choy, R.W.; Cheng, Z.; Schekman, R. Amyloid precursor protein (APP) traffics from the cell surface via endosomes for amyloid beta (Abeta) production in the trans-Golgi network. Proc. Natl. Acad. Sci. USA 2012, 109, E2077-E2082. [CrossRef] [PubMed]

34. Pietrzik, C.U.; Yoon, I.S.; Jaeger, S.; Busse, T.; Weggen, S.; Koo, E.H. FE65 constitutes the functional link between the low-density lipoprotein receptor-related protein and the amyloid precursor protein. J. Neurosci. 2004, 24, 4259-4265. [CrossRef]

35. Griciuc, A.; Serrano-Pozo, A.; Parrado, A.R.; Lesinski, A.N.; Asselin, C.N.; Mullin, K.; Hooli, B.; Choi, S.H.; Hyman, B.T.; Tanzi, R.E. Alzheimer's Disease Risk Gene CD33 Inhibits Microglial Uptake of Amyloid Beta. Neuron 2013, 78, 631-643. [CrossRef]

36. Wyss-Coray, T.; Loike, J.D.; Brionne, T.C.; Lu, E.; Anankov, R.; Yan, F.; Silverstein, S.C.; Husemann, J. Adult mouse astrocytes degrade amyloid-beta in vitro and in situ. Nat. Med. 2003, 9, 453-457. [CrossRef]

37. Deane, R.; Wu, Z.; Sagare, A.; Davis, J.; Du, Y.S.; Hamm, K.; Xu, F.; Parisi, M.; LaRue, B.; Hu, H.W.; et al. LRP/amyloid beta-peptide interaction mediates differential brain efflux of Abeta isoforms. Neuron 2004, 43, 333-344. [CrossRef]

38. Walker, J.R.; Pacoma, R.; Watson, J.; Ou, W.; Alves, J.; Mason, D.E.; Peters, E.C.; Urbina, H.D.; Welzel, G.; Althage, A.; et al. Enhanced Proteolytic Clearance of Plasma A+; by Peripherally Administered Neprilysin Does Not Result in Reduced Levels of Brain A $\beta$ in Mice. J. Neurosci. 2013, 33, 2457-2464. [CrossRef]

39. Fukumoto, H.; Tennis, M.; Locascio, J.J.; Hyman, B.T.; Growdon, J.H.; Irizarry, M.C. Age but not diagnosis is the main predictor of plasma amyloid beta-protein levels. Arch. Neurol. 2003, 60, 958-964.

40. Mehta, P.D.; Pirttila, T.; Patrick, B.A.; Barshatzky, M.; Mehta, S.P. Amyloid beta protein 1-40 and 1-42 levels in matched cerebrospinal fluid and plasma from patients with Alzheimer disease. Neurosci. Lett. 2001, 304, 102-106. [CrossRef]

41. Siemers, E.R.; Dean, R.A.; Friedrich, S.; Ferguson-Sells, L.; Gonzales, C.; Farlow, M.R.; May, P.C. Safety, tolerability, and effects on plasma and cerebrospinal fluid amyloid-beta after inhibition of gamma-secretase. Clin. Neuropharmacol. 2007, 30, 317-325. [CrossRef] [PubMed]

42. Albani, D.; Marizzoni, M.; Ferrari, C.; Fusco, F.; Boeri, L.; Raimondi, I.; Jovicich, J.; Babiloni, C.; Soricelli, A.; Lizio, R.; et al. Plasma Abeta42 as a Biomarker of Prodromal Alzheimer's Disease Progression in Patients with Amnestic Mild Cognitive Impairment: Evidence from the PharmaCog/E-ADNI Study. J. Alzheimers Dis. 2019, 69, 37-48. [CrossRef] [PubMed]

43. Sutcliffe, J.G.; Hedlund, P.B.; Thomas, E.A.; Bloom, F.E.; Hilbush, B.S. Peripheral reduction of beta-amyloid is sufficient to reduce brain beta-amyloid: Implications for Alzheimer's disease. J. Neurosci. Res. 2011, 89, 808-814. [CrossRef]

44. Bassendine, M.F.; Taylor-Robinson, S.D.; Fertleman, M.; Khan, M.; Neely, D. Is Alzheimer's Disease a Liver Disease of the Brain? J. Alzheimer Dis. 2020, 75, 1-14. [CrossRef] [PubMed]

45. Roberts, K.F.; Elbert, D.L.; Kasten, T.P.; Patterson, B.W.; Sigurdson, W.C.; Connors, R.E.; Ovod, V.; Munsell, L.Y.; Mawuenyega, K.G.; Miller-Thomas, M.M.; et al. Amyloid-beta efflux from the central nervous system into the plasma. Ann. Neurol. 2014, 76, 837-844. [CrossRef] [PubMed]

46. Boada, M.; Lopez, O.L.; Olazaran, J.; Nunez, L.; Pfeffer, M.; Paricio, M.; Lorites, J.; Pinol-Ripoll, G.; Gamez, J.E.; Anaya, F.; et al. A randomized, controlled clinical trial of plasma exchange with albumin replacement for Alzheimer's disease: Primary results of the AMBAR Study. Alzheimers Dement 2020, 16, 1412-1425. [CrossRef] [PubMed]

47. Zhang, L.; Dasuri, K.; Fernandez-Kim, S.O.; Bruce-Keller, A.J.; Freeman, L.R.; Pepping, J.K.; Beckett, T.L.; Murphy, M.P.; Keller, J.N. Prolonged diet induced obesity has minimal effects towards brain pathology in mouse model of cerebral amyloid angiopathy: Implications for studying obesity-brain interactions in mice. Biochim. Biophys. Acta 2013, 1832, 1456-1462. [CrossRef]

48. Li, J.; Deng, J.; Sheng, W.; Zuo, Z. Metformin attenuates Alzheimer's disease-like neuropathology in obese, leptin-resistant mice. Pharmacol. Biochem. Behav. 2012, 101, 564-574. [CrossRef] 
49. Puig, K.L.; Floden, A.M.; Adhikari, R.; Golovko, M.Y.; Combs, C.K. Amyloid precursor protein and proinflammatory changes are regulated in brain and adipose tissue in a murine model of high fat diet-induced obesity. PLOS ONE 2012, 7, e30378. [CrossRef]

50. Wang, J.; Gu, B.J.; Masters, C.L.; Wang, Y.-J. A systemic view of Alzheimer disease - insights from amyloid- $\beta$ metabolism beyond the brain. Nat. Rev. Neurol. 2017, 13, 612-623. [CrossRef]

51. Ostrowski, P.P.; Barszczyk, A.; Forstenpointner, J.; Zheng, W.; Feng, Z.P. Meta-Analysis of Serum Insulin-Like Growth Factor 1 in Alzheimer's Disease. PLoS ONE 2016, 11, e0155733. [CrossRef] [PubMed]

52. Paulsen, A.J.; Schubert, C.R.; Pinto, A.; Carlsson, C.M.; Chappell, R.J.; Fischer, M.E.; Klein, B.E.K.; Klein, R.; Tsai, M.Y.; Cruickshanks, K.J. Neuroprotective Biomarkers and Cognitive Function in a Long-Term Prospective Population-based Study of Aging US Adults. Alzheimer Dis. Assoc. Disord. 2019, 34, 31-39. [CrossRef] [PubMed]

53. Almeida, O.P.; Hankey, G.J.; Yeap, B.B.; Paul Chubb, S.A.; Gollege, J.; Flicker, L. Risk of prevalent and incident dementia associated with insulin-like growth factor and insulin-like growth factor-binding protein 3. Mol. Psychiatry 2017, 23, 1825-1829. [CrossRef] [PubMed]

54. Lanz, T.A.; Salatto, C.T.; Semproni, A.R.; Marconi, M.; Brown, T.M.; Richter, K.E.; Schmidt, K.; Nelson, F.R.; Schachter, J.B. Peripheral elevation of IGF-1 fails to alter Abeta clearance in multiple in vivo models. Biochem. Pharmacol. 2008, 75, 1093-1103. [CrossRef] [PubMed]

55. Petrov, D.; Pedros, I.; Artiach, G.; Sureda, F.X.; Barroso, E.; Pallas, M.; Casadesus, G.; Beas-Zarate, C.; Carro, E.; Ferrer, I.; et al. High-fat diet-induced deregulation of hippocampal insulin signaling and mitochondrial homeostasis deficiences contribute to Alzheimer disease pathology in rodents. Biochim. Biophys. Acta 2015, 1852, 1687-1699. [CrossRef]

56. Servick, K. Of mice and microbes. Science 2016, 353, 741-743. [CrossRef]

57. Jensen, E.A.; Young, J.A.; Mathes, S.C.; List, E.O.; Carroll, R.K.; Kuhn, J.; Onusko, M.; Kopchick, J.J.; Murphy, E.R.; Berryman, D.E. Crosstalk between the growth hormone/insulin-like growth factor-1 axis and the gut microbiome: A new frontier for microbial endocrinology. Growth Horm. IGF Res. 2020, 53, 101333. [CrossRef]

58. Jimenez, S.; Torres, M.; Vizuete, M.; Sanchez-Varo, R.; Sanchez-Mejias, E.; Trujillo-Estrada, L.; Carmona-Cuenca, I.; Caballero, C.; Ruano, D.; Gutierrez, A.; et al. Age-dependent accumulation of soluble Abeta oligomers reverses the neuroprotective effect of sAPPalpha by modulating PI3K/Akt-GSK-3beta pathway in Alzheimer mice model. J. Biol. Chem. 2011, 286, 18414-18425. [CrossRef]

59. Gasparini, L.; Gouras, G.K.; Wang, R.; Gross, R.S.; Beal, M.F.; Greengard, P.; Xu, H. Stimulation of beta-amyloid precursor protein trafficking by insulin reduces intraneuronal beta-amyloid and requires mitogen-activated protein kinase signaling. J. Neurosci. 2001, 21, 2561-2570. [CrossRef]

60. Kaiyala, K.J.; Prigeon, R.L.; Kahn, S.E.; Woods, S.C.; Schwartz, M.W. Obesity induced by a high-fat diet is associated with reduced brain insulin transport in dogs. Diabetes 2000, 49, 1525-1533. [CrossRef]

61. Banks, W.A.; Coon, A.B.; Robinson, S.M.; Moinuddin, A.; Shultz, J.M.; Nakaoke, R.; Morley, J.E. Triglycerides induce leptin resistance at the blood-brain barrier. Diabetes 2004, 53, 1253-1260. [CrossRef] [PubMed]

62. Carro, E.; Trejo, J.L.; Gerber, A.; Loetscher, H.; Torrado, J.; Metzger, F.; Torres-Aleman, I. Therapeutic actions of insulin-like growth factor I on APP/PS2 mice with severe brain amyloidosis. Neurobiol. Aging 2006, 27, 1250-1257. [CrossRef] [PubMed]

63. Van Veluw, S.J.; Hou, S.S.; Calvo-Rodriguez, M.; Arbel-Ornath, M.; Snyder, A.C.; Frosch, M.P.; Greenberg, S.M.; Bacskai, B.J. Vasomotion as a Driving Force for Paravascular Clearance in the Awake Mouse Brain. Neuron 2019, 105, 549-561. [CrossRef] [PubMed]

64. Iliff, J.J.; Wang, M.; Liao, Y.; Plogg, B.A.; Peng, W.; Gundersen, G.A.; Benveniste, H.; Vates, G.E.; Deane, R.; Goldman, S.A.; et al. A Paravascular Pathway Facilitates CSF Flow Through the Brain Parenchyma and the Clearance of Interstitial Solutes, Including Amyloid ß. Sci. Transl. Med. 2012, 4, 147ra111. [CrossRef]

65. Yamamoto, N.; Ishikuro, R.; Tanida, M.; Suzuki, K.; Ikeda-Matsuo, Y.; Sobue, K. Insulin-signaling Pathway Regulates the Degradation of Amyloid beta-protein via Astrocytes. Neuroscience 2018, 385, 227-236. [CrossRef]

66. Fernandez, A.M.; Hernandez, E.; Guerrero-Gomez, D.; Miranda-Vizuete, A.; Torres Aleman, I. A network of insulin peptides regulate glucose uptake by astrocytes: Potential new druggable targets for brain hypometabolism. Neuropharmacology 2018, 136, 216-222. [CrossRef] 
67. Katsouri, L.; Birch, A.M.; Renziehausen, A.W.J.; Zach, C.; Aman, Y.; Steeds, H.; Bonsu, A.; Palmer, E.O.C.; Mirzaei, N.; Ries, M.; et al. Ablation of reactive astrocytes exacerbates disease pathology in a model of Alzheimer's disease. Glia 2019, 68, 1017-1030. [CrossRef]

68. Baik, S.H.; Kang, S.; Son, S.M.; Mook-Jung, I. Microglia contributes to plaque growth by cell death due to uptake of amyloid beta in the brain of Alzheimer's disease mouse model. Glia 2016, 64, 2274-2290. [CrossRef]

69. Grathwohl, S.A.; Kalin, R.E.; Bolmont, T.; Prokop, S.; Winkelmann, G.; Kaeser, S.A.; Odenthal, J.; Radde, R.; Eldh, T.; Gandy, S.; et al. Formation and maintenance of Alzheimer's disease [beta]-amyloid plaques in the absence of microglia. Nat. Neurosci. 2009, 12, 1361-1363.

70. Sosna, J.; Philipp, S.; Albay, R., 3rd; Reyes-Ruiz, J.M.; Baglietto-Vargas, D.; LaFerla, F.M.; Glabe, C.G. Early long-term administration of the CSF1R inhibitor PLX3397 ablates microglia and reduces accumulation of intraneuronal amyloid, neuritic plaque deposition and pre-fibrillar oligomers in 5XFAD mouse model of Alzheimer's disease. Mol. Neurodegener. 2018, 13, 11. [CrossRef]

71. Pitt, J.; Wilcox, K.C.; Tortelli, V.; Diniz, L.P.; Oliveira, M.S.; Dobbins, C.; Yu, X.W.; Nandamuri, S.; Gomes, F.C.A.; DiNunno, N.; et al. Neuroprotective astrocyte-derived insulin/insulin-like growth factor 1 stimulates endocytic processing and extracellular release of neuron-bound Abeta oligomers. Mol. Biol. Cell 2017, 28, 2623-2636. [CrossRef] [PubMed]

72. Belyaev, N.D.; Kellett, K.A.; Beckett, C.; Makova, N.Z.; Revett, T.J.; Nalivaeva, N.N.; Hooper, N.M.; Turner, A.J. The transcriptionally active amyloid precursor protein (APP) intracellular domain is preferentially produced from the 695 isoform of APP in a \{beta\}-secretase-dependent pathway. J. Biol. Chem. 2010, 285, 41443-41454. [CrossRef] [PubMed]

73. Jaeger, L.B.; Dohgu, S.; Hwang, M.C.; Farr, S.A.; Murphy, M.P.; Fleegal-DeMotta, M.A.; Lynch, J.L.; Robinson, S.M.; Niehoff, M.L.; Johnson, S.N.; et al. Testing the neurovascular hypothesis of Alzheimer's disease: LRP-1 antisense reduces blood-brain barrier clearance, increases brain levels of amyloid-beta protein, and impairs cognition. J. Alzheimers. Dis. 2009, 17, 553-570. [CrossRef] [PubMed]

74. Yakar, S.; Setser, J.; Zhao, H.; Stannard, B.; Haluzik, M.; Glatt, V.; Bouxsein, M.L.; Kopchick, J.J.; LeRoith, D. Inhibition of growth hormone action improves insulin sensitivity in liver IGF-1-deficient mice. J. Clin. Investig. 2004, 113, 96-105. [CrossRef] [PubMed]

75. Sjogren, K.; Jansson, J.O.; Isaksson, O.G.; Ohlsson, C. A transgenic model to determine the physiological role of liver-derived insulin-like growth factor I. Minerva Endocrinol. 2002, 27, 299-311. [PubMed]

76. Fernandez, A.M.; Fernandez, S.; Carrero, P.; Garcia-Garcia, M.; Torres-Aleman, I. Calcineurin in reactive astrocytes plays a key role in the interplay between proinflammatory and anti-inflammatory signals. J. Neurosci. 2007, 27, 8745-8756. [CrossRef]

77. Trueba-Saiz, A.; Fernandez, A.M.; Nishijima, T.; Mecha, M.; Santi, A.; Munive, V.; Torres-Aleman, I. Circulating Insulin-like Growth Factor I Regulates Its Receptor in the Brain of Male Mice. Endocrinology 2017, 158, 349-357. [CrossRef]

78. Ayala, J.E.; Samuel, V.T.; Morton, G.J.; Obici, S.; Croniger, C.M.; Shulman, G.I.; Wasserman, D.H.; McGuinness, O.P.; Consortium, N.I.H.M.M.P.C. Standard operating procedures for describing and performing metabolic tests of glucose homeostasis in mice. Dis. Model. Mech. 2010, 3, 525-534. [CrossRef]

79. Trueba-Saiz, A.; Cavada, C.; Fernandez, A.M.; Leon, T.; Gonzalez, D.A.; Fortea, O.J.; Lleo, A.; Del, S.T.; Nunez, A.; Torres-Aleman, I. Loss of serum IGF-I input to the brain as an early biomarker of disease onset in Alzheimer mice. Transl. Psychiatry 2013, 3, e330. [CrossRef]

80. Liu, C.C.; Hu, J.; Zhao, N.; Wang, J.; Wang, N.; Cirrito, J.R.; Kanekiyo, T.; Holtzman, D.M.; Bu, G. Astrocytic LRP1 Mediates Brain Abeta Clearance and Impacts Amyloid Deposition. J. Neurosci. 2017, 37, 4023-4031. [CrossRef]

81. Fernandez, A.M.; Jimenez, S.; Mecha, M.; Davila, D.; Guaza, C.; Vitorica, J.; Torres-Aleman, I. Regulation of the phosphatase calcineurin by insulin-like growth factor I unveils a key role of astrocytes in Alzheimer's pathology. Mol. Psychiatry 2012, 17, 705-718. [CrossRef] [PubMed]

82. Teich, A.F.; Patel, M.; Arancio, O. A Reliable Way to Detect Endogenous Murine $\beta$-Amyloid. PLoS ONE 2013, 8, e55647. [CrossRef] [PubMed] 
83. Martinez-Rachadell, L.; Aguilera, A.; Perez-Domper, P.; Pignatelli, J.; Fernandez, A.M.; Torres-Aleman, I. Cell-specific expression of insulin/insulin-like growth factor-I receptor hybrids in the mouse brain. Growth Horm. IGF Res. 2019, 45, 25-30. [CrossRef] [PubMed]

84. Sevigny, J.J.; Ryan, J.M.; van Dyck, C.H.; Peng, Y.; Lines, C.R.; Nessly, M.L. Growth hormone secretagogue MK-677: No clinical effect on AD progression in a randomized trial. Neurology 2008, 71, 1702-1708. [CrossRef] [PubMed]

Publisher's Note: MDPI stays neutral with regard to jurisdictional claims in published maps and institutional affiliations.

(C) 2020 by the authors. Licensee MDPI, Basel, Switzerland. This article is an open access article distributed under the terms and conditions of the Creative Commons Attribution (CC BY) license (http://creativecommons.org/licenses/by/4.0/). 